\title{
Regulating Convergence: Challenges for Contemporary Media in Indonesia
}

\author{
Hellena Yoranita Souisa \\ The University of Melbourne - Asia Institute, Parkville - Victoria 3010, Australia, +61406742121, \\ hsouisa@student.unimelb.edu.au
}

\begin{abstract}
This paper examines the implications of media liberalization and media convergence to regulatory issues and journalism practices in Indonesia. While technologies are being used to serve the economic interests of media companies, corporate concentration and technological convergence effectively disempower media workers. It will do so through an in-depth analysis of the current trends and case studies in the Indonesian media industry. The Indonesian case shows how media liberalization affects Indonesian media landscape at a first place, and how the media landscape is then shaped by conglomeration and convergence. Using the concept of diversity, media scholars are still debating the consequences of liberalization and convergence, to see whether those will undermine journalism and threaten the diversity of voices as the heart of media in democracy. This creates another challenge for regulatory bodies in Indonesia. On one hand, a free and competitive economic marketplace, a consideration of competitive markets is critical. On the other hand, there should be some tools to ensure media pluralism and diversity (ownership and content), hence provide necessary protections for the public. May there are interventions needed from the government body regarding this double-edge sword situation, a clear distinction needs to be drawn between regulation in the public interest and regulation to protect against market failure.
\end{abstract}

Keywords: Indonesia; media ownership, media concentration, convergence, content diversity, political economy, policy

\section{Introduction}

Independent media is essential to democracy for many reasons. In order to make elections work, for example, it is the duty of the media to provide citizens with accurate information, as democracy requires an informed citizenry. Independent media in democracy is an arena where the exchange of a diverse range of information and views facilitates the formation of public opinion. It took the fall of the almost 32 year-long authoritarian New Order regime (1967-1998) before Indonesians finally experienced democracy again in $1998^{1}$. The spirit of democracy was reflected in the implementation of the new Press Law in 1999, which is more liberal and free from government control than the old law. This has resulted in a growing number of media outlets. The new Press Law is in line with Mugan and Gunther's (2000: 5) observation that media under a democratic system are supposed to be free from direct political control and should be protected by legal frameworks that "promote and sustain a diversity of media forms and outlets". Diversity of media outlets and content is an essential aspect of Indonesia's new democracy, but previous research has shown that this diversity has been challenged by various developments within the Indonesian media landscape.

This research examines the 'convergence era' Jenkins, 2006; Mulligan, 2012), which is amongst significant factor that 
challenges the diversity of media outlets and contents. Grant and Wilkinson (2009: 15) describe convergence as 'a revolution that is sweeping the media industries'. While there is no unanimously accepted definition of convergence (Gordon, 2003), it is regarded as a phenomenon which influences the media system, shaping the different dimensions of communication: technological, professional, structural and operational (Erdal, 2007). The main case-study will be one of the media group in Indonesia, Media Nusantara Citra or known as MNC Group. Under this introduction section, I will present brief background of contemporary Indonesian media landscape, followed by the logic and types of media convergence in general, before finally jump into the case study of Media Nusantara Citra model of convergence in Indonesia and the challenges in regulating this phenomenon in result and discussion section. Later on in this article, we will see whether this phenomenon is the one that "pushing the media industry in new directions of integration, synchronisation, and conglomeration" (Tapsell, 2011: 183) in Indonesia or whether those situations are intertwined. The examination is important in order to decide to what extent such regulations on convergence are needed.

\section{The Indonesian media landscape: from darkness to conglomerates}

As a result of reformasi ${ }^{2}$, Indonesian media industries have been expanding for the last two decades. After 32 years of tight media control under the New Order, the department of communication which used to be the executioner of any government policy toward the media was dismissed. Moreover, the more liberal Press Law was implemented, giving the media the freedom to serve public interests without the fear of being banned. The situation after reformasi, was in accordance to the perspective of market liberal theorists from the standpoint of political theory where regulation of the media is kept to a minimum so that the 'marketplace of ideas' can operate in as full and free manner as possible (Dryzek and Dunleavy, 2009: 101-127). Inline with market liberal theories is the fourth estate theories from the standpoint of media and journalism theories. Bray (1965, pp.13-15) argues that as the fourth estate, the media is responsible to act as 'guardian' of the people's fundamental right to free expression of opinion, 'watchdog' of civil liberties, and 'protector' against the bureaucrats or assuming authority against the common man (in Schultz, 1998: 43). At the heart of this role is "structurally independence from the state, and minimal regulation of the media" (Flew \& Swift, 2013: 6). The new law in Indonesia no longer requires licenses for opening media business, especially the print media, which has resulted in the rising number of media outlets as shown in Table 1. As for broadcast media, the situation is more problematic, considering that before 1998 Indonesia has not had a broadcasting regulation. Since the main players of commercial television were Suharto's family, licenses were given without clear mechanism and process. 
Table 1. Indonesian Media Landscape: Number of Outlets (Under and Post-Suharto)

\begin{tabular}{lll|}
\hline Media Outlet & $\mathbf{1 9 9 8}$ & $\mathbf{2 0 1 3}$ \\
\hline $\begin{array}{l}\text { Print Media } \\
\text { Radio }\end{array}$ & 298 & 1,076 \\
Television & 700 & 2,800 \\
& 6 & 11 \\
\hline
\end{tabular}

Source: Author, compiling data from Lim, 2011; Haryanto, in Sen and Hill, 2011; Sudibyo and Patria, 2013

Additionally, in 2015 the Ministry of Communication and Information Technology reported that the number of Indonesian Internet users had reach 82 million or about $35 \%$ of the total population, showing a dramatic growth from only 618,000 users or $0.26 \%$ in 1998 . Each medium makes unique contributions to social and political learning. Whereas audiences would traditionally read their morning newspaper over breakfast or on the train to work, and watch the 8 o'clock news on television, new media such as the Internet have given people the option to steal quick peeks at news headlines throughout the day (Gillmor, 2006; Siapera, 2012). Interactivity has also increased. Because of these developments, the mainstream media can no longer treat the news as a one-way lecture. The mainstream media is now aware that it is no longer an era of 'we told you what the news is' or 'you buy it, or you don't' (Gillmor, 2006: XXIV).

Although Table 1 shows the number of media outlets in Indonesia has increased significantly since 1998, currently only 13 large media groups control almost all of Indonesia's media channels in print, broadcast, and online media (Lim, 2011; Haryanto, 2011; Nugroho, 2012; Sudibyo and Patria, 2013). The overview of media ownership as presented in Table 2 shows the existence of media conglomerations. Masduki (2014: 3) defines a conglomerate as "a large company composed of smaller companies engaged in seemingly related or unrelated business". Gillian Doyle (2002: 13) further specifies media ownership concentration according to the following patterns:

'Monomedia concentrations' (horizontal) refers to concentrated ownership within a single sector of activity. 'Cross-media concentrations' reflect either vertical or diagonal integration, or both. 'Vertical integration' refers to common ownership across different phases in the supply chain for a media product (television program making/production and television broadcasting/distribution).

'Diagonal integration' means common ownership between different media sectors (television and newspapers, or newspapers and radio).

These configurations of media ownership also apply to the Indonesian media landscape, as I will demonstrate later in this chapter. 
Table 2. Major Indonesian Media Groups in 2016

\begin{tabular}{|c|c|c|c|c|c|}
\hline Media Group - Owner & Television & Print & Radio & Online & Other \\
\hline $\begin{array}{l}\text { Media Nusantara Citra } \\
\text { (MNC) Group - } \\
\text { HaryTanoesoedibjo }\end{array}$ & $\begin{array}{l}\text { RCTI, GlobalTV, } \\
\text { MNCTV, iNewsTV }\end{array}$ & $\begin{array}{l}\text { Seputar Indonesia } \\
\text { Daily, Trust } \\
\text { Magazine, Tabloid } \\
\text { Genie, Mom and } \\
\text { Kiddie, High End } \\
\text { Magazine }\end{array}$ & $\begin{array}{l}\text { SindoTrijaya, Global } \\
\text { Radio, Radio Dangdut } \\
\text { Indonesia, V Radio }\end{array}$ & Okezone.com & $\begin{array}{l}\text { IT, content production and } \\
\text { distribution, talent management, } \\
\text { automobile, banking, insurance, } \\
\text { infrastructure }\end{array}$ \\
\hline $\begin{array}{l}\text { Para Group - } \\
\text { ChairulTanjung }\end{array}$ & $\begin{array}{l}\text { TransTV, Trans7, CNN } \\
\text { Indonesia }\end{array}$ & - & - & Detik.com & $\begin{array}{l}\text { Hotel, restaurants, cafés, banking, } \\
\text { retail mart, theme parks, venture } \\
\text { capital, insurance }\end{array}$ \\
\hline $\begin{array}{l}\text { Visi Media Asia (Viva) } \\
\text { Group - } \\
\text { Bakrie Family }\end{array}$ & ANTV, TVONE & - & - & Vivanews.com & $\begin{array}{l}\text { Telecommunications, property, } \\
\text { metal, oil \& gas, agribusiness, coal, } \\
\text { infrastructure }\end{array}$ \\
\hline $\begin{array}{l}\text { Mahaka Media Group - } \\
\text { Erik Tohir }\end{array}$ & JakTV & $\begin{array}{l}\text { Republika Daily, } \\
\text { Indonesia Daily, Golf } \\
\text { Digest }\end{array}$ & $\begin{array}{l}\text { GenFM, DeltaFM, } \\
\text { FemaleFM, } \\
\text { PramborsFM, JakFM }\end{array}$ & $\begin{array}{l}\text { Republika online, } \\
\text { Sportku.com, Jaktv.co.id } \\
98.7 \text { genfm.co.id } \\
\text { 101jakfm.co.id }\end{array}$ & $\begin{array}{l}\text { Content provider, Advertising, Event } \\
\text { Organizer, Marketing Company }\end{array}$ \\
\hline $\begin{array}{l}\text { KompasGramedia } \\
\text { Group - Jacob Oetama }\end{array}$ & KompasTV Network & $\begin{array}{l}\text { Kompas Daily, Jakarta } \\
\text { Post Daily, Warta } \\
\text { Kota, } 11 \text { local papers, } \\
43 \text { Magazines, Daily } \\
\text { Digest }\end{array}$ & SonoraFM, MotionFM & $\begin{array}{l}\text { Kompas.com } \\
\text { Kompas.tv }\end{array}$ & $\begin{array}{l}\text { Hotels, PR agencies, event organizer, } \\
\text { university, tissue }\end{array}$ \\
\hline $\begin{array}{l}\text { JawaPos Group - } \\
\text { DahlanIskan }\end{array}$ & $\begin{array}{l}\text { JawaPosTV, } \\
\text { JTV, BatamTV, RiauTV, } \\
\text { FajarTV, and } 8 \text { others }\end{array}$ & $\begin{array}{l}\text { JawaPos, Indo Pos, } \\
\text { Rakyat Merdeka } \\
\text { Daily, Radar and } \\
\text { other local papers } \\
\text { (151 in total), } \\
\text { Mentari, Liberty } \\
\text { Magazines \& } 11 \\
\text { tabloids }\end{array}$ & FajarFM & Jawapos.com & $\begin{array}{l}\text { Power plant, printing plant, travel } \\
\text { bureau }\end{array}$ \\
\hline $\begin{array}{l}\text { ElangMahkotaTeknologi } \\
\text { (EMTEK) Group - Eddy } \\
\text { Kusnadi }\end{array}$ & $\begin{array}{l}\text { SCTV, Indosiar, } \\
\text { O'Channel, } \\
\text { ElshintaTV }\end{array}$ & - & ElshintaFM & $\begin{array}{l}\text { Liputan6.com } \\
\text { Kmkonline } \\
\text { Karir.com }\end{array}$ & Property, home shopping, hospital \\
\hline $\begin{array}{l}\text { Media Bali Post Group } \\
\text { (KMB) - SatriaNarada }\end{array}$ & $\begin{array}{l}\text { BaliTV and other } 8 \text { local } \\
\text { stations }\end{array}$ & $\begin{array}{l}\text { Bali Post, Bisnis Bali, } \\
\text { Suluh Indonesia, } \\
\text { HarianDenpost, Suara } \\
\text { NTB, Tokoh, Lintang, } \\
\text { Wiyata Mandala }\end{array}$ & $\begin{array}{l}\text { Global KiniJani, Genta } \\
\text { FM, and } 5 \text { others }\end{array}$ & - & - \\
\hline $\begin{array}{l}\text { Lippo Group - Riady } \\
\text { Family }\end{array}$ & BeritaSatu TV & $\begin{array}{l}\text { SuaraPembaruan, } \\
\text { Investor Daily }\end{array}$ & - & BeritaSatu.com & $\begin{array}{l}\text { Property, banking, education, } \\
\text { insurance, shopping malls, retail mart }\end{array}$ \\
\hline $\begin{array}{l}\text { Femina Group - } \\
\text { PiaAlisyahbana } \\
\text { MirtaKartohadi } \\
\end{array}$ & - & $\begin{array}{l}\text { Femina, Gadis, Dewi, } \\
\text { Ayah Bunda, and } 11 \\
\text { others }\end{array}$ & - & $\begin{array}{l}\text { Femina, Ayahbunda, Gadis, } \\
\text { Parenting online }\end{array}$ & $\begin{array}{l}\text { Production house, event } \\
\text { management, boutique, education, } \\
\text { printing }\end{array}$ \\
\hline $\begin{array}{l}\text { Media Indonesia Group } \\
\text {-Surya Paloh }\end{array}$ & MetroTV & $\begin{array}{l}\text { Media Indonesia } \\
\text { Daily, Lampung Post, } \\
\text { Borneo News }\end{array}$ & - & $\begin{array}{l}\text { Media Indonesia } \\
\text { Metrotvnews }\end{array}$ & Hotel, property, catering, oil, coal \\
\hline $\begin{array}{l}\text { Tempo Group - Yayasan } \\
\text { Tempo }\end{array}$ & TempoTV Network & $\begin{array}{l}\text { Tempo Daily, Tempo } \\
\text { Magazine, } \\
\text { Travelounge }\end{array}$ & - & Tempo.co & Publishing \\
\hline $\begin{array}{l}\text { MugiRekaAditama } \\
\text { (MRA) Group - Dian } \\
\text { MS }\end{array}$ & - & $\begin{array}{l}\text { Cosmopolitan, } \\
\text { Cosmogirl, Fitness, } \\
\text { and } 13 \text { others }\end{array}$ & $\begin{array}{l}\text { CosmopolitanFM } \\
\text { Hard Rock FM } \\
\text { I-Radio } \\
\text { TraxFM }\end{array}$ & - & Holder of several boutique brands \\
\hline
\end{tabular}

Source: Author, compiling data from Lim, M. 2011; Haryanto, I. in Sen and Hill, 2011; Nugroho, 2012; Sudibyo and Patria, 2013; and media corporates' official website

Similar to the previous findings of Lim (2011), a report by the Centre for Innovation Policy and Governance in 2012 also came to the conclusion that Indonesian media ownership is concentrated in 12 large groups, which is slightly different with Table 2 above that showing 13 groups 5 . Louis Day (2006: 249) points out that media concentration "could result in a better product because of the pooling of economic resources," especially if "parent companies do not intrude into the editorial decisions of their news operations" (Ibid). Demers and Merskin (quoted by Winscek, 2007: 43-44) also argue that the potential for media owners to influence contents has been sharply diminished by the rise of modern corporations, including conglomerations, with "actual control resting in the hands of expert managers, with media workers relatively free to do as they please within the limits of professional standards and good business practice." Clearly, those perspectives still view no problem on the concentration of media ownership as the threat to press freedom is seen as coming from governments, rather than from media owners. In a contrary, Nugroho (2012) points out that 
the citizen's right to information has been threatened by the media oligopoly that is entirely profit driven. His point of view is aligned to the political economy theorists that view media differently than market liberal perspective.

While the market liberal theorists see media as independent entities, critical political economy does not view mass media as valuefree institutions that produce contents reflecting reality, in order to empower people so they become informed citizens in democratic society. Rather, it sees mass media as part of the products of industrial capitalism (Garnham \& Inglis, 1990). Moreover, Meikle and Young (2012: 50) argue that news has to be seen as a product. It means, "news is not a natural category of events that are simply found and presented by journalists, but is produced and marketed on an industrial scale by media organizations" (Ibid). In other words, media organisations do not only provide 'news' per se, but also part the political and ideological processes of economic markets. This perspective from the critical political economy is relevant and important not only to examine the concentration of media ownership in Indonesia, but also to observe media convergence.

\section{Theoretical Perspective}

Welcome to the family, the youngest kin: media convergence

The trend on the concentration of media ownership as the impact of liberalization happens not only in Indonesia, but across the globe. Ben Bagdikian in his book Media Monopoly (2000)analyses the same trend of concentration of media ownership in the United States. While Indonesia was still under authoritarian regime and had yet independent media, the United States has already moved by deregulating its media ownership policy to be more relaxed in 1986. Compaine (2001) explained that in 1986 US households had access to only three commercial networks, whereas in 2001 there were six commercial broadcast networks controlled by five corporate owners. Deregulation also happened in Europe. Only, the relaxation and rationalisation of media ownership in Germany in 1996 and France in 1994 were driven by digitalisation technology (Levy, 2007). This rapid development in technology leads us to the contemporary media world, which according to Ithiel de Sola Pool is "the result of evolutionary change with revolutionary consequences commonly characterised as convergence" (Gordon, 2003).

There are diverse definitions of convergence. Some focus on "overlapping systems and others on efficiency, while some place technology in the foreground and still others emphasize organizational mergers" (Drucker \& Gumpert, 2010:1). For Gundelsweiler and Filk (2012: 47) the term media convergence "first referred primarily to the technical convergence of print media to electronic media and telecommunications", whilst from the perspective of convergence in journalism, Gordon (2003) identifies five characteristics of convergence: ownership, tactics, structure, information gathering, and presentation/storytelling. Henry Jenkins (2004: 34), moreover, underlines an important argument of media convergence that more than simply a technological shift but "refers to a process, and not an endpoint. It alters the relationship between existing technologies, industries, markets, genres, and audiences." On top of various definitions of convergence, for the purpose of this paper I divide media convergence into two main categories: technological convergence and structural (industry/market) convergence. In the following paragraph, I will elaborate the first category of technological convergence in general and in Indonesia, before I discuss the second category of structural convergence by using the case study of Media Nusantara Citra on the next section. 
Looking back to the push factor of deregulation media in some European countries was the digital technology. From the standpoint of technology, the shift from analogue to digital is basic to convergence. This shows what Drucker and Grumpet (2010: 2) meant by saying "at the heart of technological convergence are digitalisation and the conversion of messages into a binary code of $0 \mathrm{~s}$ and $1 \mathrm{~s}$ ". With electronic media, sound and light waves are coded into electronic form for transmission and reception. As Grant and Wilkinson (2009: 5) explain:

... the first electronic media were designed to capture, record, transmit, receive, and amplify these waves. The different wavelengths for sound and light, along with the different bandwidth needed for light versus sound led to the creation of technologies that dealt with the two in different ways.

Moreover, Levy (2007: 26) points out that "digital convergence promised to break past sectoral divisions between computing, telecoms, and broadcasting, opening the way for the TV to be used as an access point to the Internet, for TV to be viewed on a desktop PC, or even for TV to be available via the Internet. "It means we are "entering an era where media will be everywhere and we will use all kinds of media in relation to each other" (Jenkins, 2004: 34). In other words, now we use our mobile phone not as telecommunication device only, but also (mainly) to download information from the Internet, receive and send emails or photographs, even to play games.

\subsection{Mission is yet accomplished: regulating} (technological) convergence in Indonesia

Responding to the technological convergence that undoubtedly has been happening in Indonesia, the government tried to come up with the draft of Convergence Bill (Undang-undang Konvergensi dan Telematika) in
2010. The bill is considered crucial because the existing media regulations are platform-based. After Indonesian President Suharto stepped down, Indonesian media entered a new chapter marked by the 1999 Press Law which ended government licensing as a way to ban publications, hence promoting and guaranteeing freedom of the press. Another regulation is the 2002 Indonesian Broadcasting Law. As the implications, there are 4 major institutions that regulate media in Indonesia. It is the Ministry of Information and Communication who officially regulates the sector, but when it comes to ethical questions regarding journalism practices (for either print or broadcast or online media), cases will be handled by the Press Council (Dewan Pers). However, because the specific identity of broadcast media, the Indonesian Broadcasting Commission (KPI/ Komisi Penyiaran Indonesia) is the one who has authority to regulate TV and radio contents (both journalistic and nonjournalistic products), including mediating disputes, monitoring and evaluating media's content, and issuing warnings and giving sanctions when there's any stations trespassing the Broadcasting Codes (P3SPS/ Pedoman Perilaku Penyiaran dan Standar Program Siaran). Another regulator is from the standpointof media as business entities: the Commission for the Supervision of Business Competition (KPPU/ Komisi Pengawasan Persaingan Usaba). It's been already 6 years since the government finished the draft in 2010, and yet the situation remains. The draft has been standing there and has not been passed as a bill.

The heart of most criticisms about this draft lays in the working definition of 'convergence' itself. As 'convergence' covers telecoms, computing, and broadcasting sector, the draft focuses mainly on telecoms and computing. Chapter 1 point 1 and 2 on the draft specifically mentions "telecommunication and telematics" but not "broadcasting" (Positioning paper KPPU on the draft of the Convergence Bill). Yuliandre Darwis, a 
Commissioner at the Indonesian Broadcasting Commission (2016, personal communication) regrets the exclusion of broadcasting sector in the draft bill, as it would be impacted the most by the convergence. However, he also admits the complication of the draft if the parliament passed it as a bill:

The Indonesian Broadcasting Commission will be very happy if the bill also embraces broadcasting sector. For us in KPI, our interest is always about the content of the media. Thus, we have to anticipate some potential changes that might occur in our media contentas the impact of convergence.

Deeper than Darwis, Indonesian media scholar who is also a member of National Coalition for Broadcasting Reform (Koalisi Nasional Reformasi Penyiaran/ KNRP), Ignatius Haryanto (2016, personal communication) underlines the need to examine the implications of convergence toward public interest. $\mathrm{He}$ argues, "although because of the rapid development of technology both sectors (broadcasting and telecommunication) now are inseparable, some basic principles to protect public interest should be served so it will not create oligopoly or monopoly. That is why the bill should contain, therefore regulate, broadcasting sector. "Having said that, it is important at this stage to examine the impact and consequences between media convergence and media ownership.

Convergence between telecoms, broadcasting, and computing appeared to make traditional restrictions on cross-media ownership obsolete, because the convergence era opens new possibilities for media become multiplatform. This means, by mastering the digital technology, one organisation can have multiplatform outlets, which provide the information that best suits citizens' preferred medium, at any time or place.From the "outlets" point of view, convergence seems giving a fresh air to media pluralism. However, we have to also consider Bernier (2008) who argues that the increase of news outlets and platforms does not automatically translate to greater news pluralism (in Goyette-Côté et al, 2012). Additionally, Robert McChesney $(2001,2002)$ contends that the problem is not the number of media outlets that are available, but how diverse the contents of those outlets are. The idea of market-driven media, or simply put, giving the media to the market mechanism undermines the idea of the media as 'public goods'. Although not using the terms of "outlet" and "content", Winscek (2008) suggests we should distinguish 'numerical diversity' (the number of channels available in any given area) from 'source diversity' (the number of media owners in any given area). Coming out from this premise of 'outlet' vs 'content' diversity, looking at the contemporary Indonesian media landscape, and how technological convergence in Indonesia is still problematic, the goal of this paper is to observe the second category of structural convergence by using Media Nusantara Citra (MNC Group) as the case study. I anticipate the case study may contribute to the completion of what is lacking in the Convergence Bill.

\section{Method}

My research focuses on professional practices in one leading media organisation undergoing structural convergence in Indonesia. The case study method was chosen as a valid tool for analyzing a complex phenomenon in its own context. This type of qualitative method relies on sources such as semi-structured personal communication interviews, written records, content analysis, and other documents to validate its conclusions. Combining my observation on MNC's media outlet, a prominent source from MNC Group has been interviewed to give inside information regarding structural convergence policy in $\mathrm{MNC}$ newsroom. In addition, I interviewed advocacy 
head division of the Alliance of Indonesian Independent Journalists (Aliansi Jumalis Independen/AJI Indonesia) and National Coalition for Broadcasting Reform (Koalisi Nasional Reformasi Penyiaran) as the representatives of Indonesian civil society, also commissioner of 2016 Indonesian Broadcasting Commission to represent regulatory bodies. All personal communications were conducted during July September 2016, two through email correspondence followed up by phone conversation, one by phone, and a one-on-one communication. All interviews are in Babasa Indonesia.

\section{Result and discussion}

The reason why I have to give some background about contemporary Indonesian media landscape, which shows media concentration, is because concentration and convergence are two distinct but interrelated processes. Hence, according to Goyette-Côté et al (2012: 755) concentration becomes reasonable for news conglomerates when it permits "the increase of synergies or convergence of content and labor in the same media group."GoyetteCôté et al continue, "it can be horizontal (various newspapers and magazines owned by the same company); vertical (by grouping the various elements of the production, editing and distribution chains within the same company), or take the form of cross-ownership (electronic media groups and print media belonging to the same company)" (Ibid).If we refer to Table 2 on Major Indonesian media group, we may see that apart from television stations, MNC Group owns newspaper, magazines, radio stations, also insurance company, infrastructure, and property business. Thus, it demonstrates both horizontal and vertical convergence, also vertical and horizontal concentration of ownership from the point of view of Gillian Doyle (2002). However, the focus of this research is on the structural (horizontal) convergence on MNC's television stations and news organisations, which actually began for almost a decade, although it intensifies on the last two years.

In the beginning there was Rajawali Citra Televisi Indonesia (RCTI). Launched on August 24th 1989 , RCTI is the first commercial television in Indonesia, owned by one of Suharto's son, Bambang Trihatmojo. A combination of financial crisis and the end of Suharto's regime caused the collapse of almost all Suharto's family businesses. One of the companies was PT. Bimantara Citra Tbk which was the holding group of RCTI. Nearly bankrupt, PT. Bimantara Citra Tbk had to gradually sell its shares of stocks to PT. Bhakti Investama owned by Hary Tanoesoedibjo. It's only by 2002 when Hary has owned the majority of shares, he changed PT. Bimantara Citra Tbk to PT. Global Mediacom Tbk (Rianto et al, 2014, p.9). PT Global Mediacom Tbk holds three main businesses: Content and Advertising-based Media under PT Media Nusantara Citra Tbk; Subscription-based Media under PT MNC Sky Vision Tbk; and online Media. On 2013, PT. Bhakti Investama changed its name to PT. MNC Investama Tbk. After obtained 100\% shares of RCTI in 2004, acquired PT. Global Informasi Bermutu (GlobalTV) in 2005, and PT. Cipta Televisi Pendidikan Indonesia (TPI, later on MNCTV) in 2006, PT Media Nusantara Citra Tbk now manages 4 national free-to-air TV stations: RCTI, MNCTV, GlobalTV and iNewsTV. Positioning itself as the first and largest national television network in Indonesia, iNewsTV has been formerly known as SindoTV (first launched in 2008 under the name of SunTV Network, which is named after its corporate name: PT. Sun Televisi Network). While Ross Tapsell (2011) mentions conglomeration as one of convergence consequences in Indonesia, I would argue that although the rapid convergence of computing and telecommunications technologies may rewrite the traditional assumptions of newsroom organisation and structure, any kinds of 
convergence is just the natural logic business of how conglomerations operate in order to maximise their profit.

Informant A has been working in TV industry since the early 2000s, and spending almost 10 years in MNC Group as a journalist. He also has been positioned in different divisions (news gathering and news production) in the newsroom. When he began his career in one of FTA TV stations of MNC, his duty was dedicated only to the station that he worked for. But things are changing gradually because of structural convergence within the MNC Group. Explanations from Informant A from insider perspective, altogether with my observation and analysis on the group's content and interviews with 3 people representing media convergence stakeholders will be used to examine the structural convergence and its implications. The findings are clustered into 4 main headings.

\section{- Integrated Newsroom}

Since early 2016, Indonesian audience should have noticed explicit differences on their TV screen when watching any channel belongs to MNC. If previously reporters were using their station's microphone cube and uniform, nowadays audience is no longer able to see the microphone cube with station's logo. Instead, reporters are using $\mathrm{MNC}$ Group microphone cube and uniform, no matters which TV station they belong to. According to Informant A (2016, personal communication), Indonesian audiences now are witnessing the implications of MNC's integrated newsroom policy. The integration started as Arya Sinulingga was appointed as MNC's news director on 2015. As Informant A explains, "since then, all TV stations under MNC gave their reporters, camerapersons, and assignment editors - basically news gathering division - under the integrated newsroom called MNC Media Gathering. We started to have a new structure and new workflows.
"MNC Media Gathering has one general manager and 5 managers working under the GM. It is the responsibility and the task of this integrated newsroom to provide news items to all 4 TV stations. The orders come from those stations which now only have producers and editors left. However, when there are similar orders from 4 stations, it does not mean that the orders are covered by 4 different teams that each is dedicated to respectively station. Instead, there will be only one team who will assign to fulfil requests from 4 different outlets.

Under this new structure and workflow, it is not only the deployment of reporters and camerapersons has changed, the portion of broadcast equipment has also simplified. MNC Media Gathering only uses 1 satellite newsgathering (SNG) to broadcast live report whereas there are 4 different outlets have to be filled, mostly at the same time. Problems then occur when there is a big news event. Naturally, each station wants to be the leading station by being the first reporting live. As Informant A recalled, there have been no standard operating procedure in this extraordinary circumstances. Imagine this: one event, covered by one team, using one technology, but serving the demands from 4 different outlets. Being a market leader for over two decades, the priority is usually given to RCTI to go live first and as the youngest child in MNC family, plus its relatively longer airtime allocated on news program, most of the times iNews comes last. However, Informant A admitted that even during the "normal" situation, it is hard for a producer to differentiate their piece to their colleague producers next door as the news materials comes from the same source. He says, "I understand that this synergy creates efficiency for the company. But now we have almost similar contents spread in 4 different outlets also because of that." 
The difficulties facing by producers in MNC Media like Informant A, especially in related to content diversity, was once explained by Singer (2004). He believes the newsroom integration may decrease the diversity of approaches that different outlets used to have towards a community. Moreover, when it happens in multiplatform media (for example: print, broadcast, online), it will ignore intrinsic differences among media formats that contribute to a heterogeneous journalistic discourse, and may lead to immediacy prevailing over analysis (Singer, 2004). In other words, media concentration, which resulted in integrated newsroom, has been narrowing the editorial control. This leads us to the next finding on how convergence can affect media content.

\section{- Multiplicity vs Diversity}

Accoding to Horwitz (2005), convergence can be observed in content as well as in the merged of labour within the same group. Now that we know about the organisation of labour within the same group in MNC, which resulted in new structure and new workflow, let us examine each platform's content. Even though RCTI, MNCTV, GlobalTV, and $i$ News $T V$ have their own producers and postproduction squad, Informant A shares his concern on how difficult to make such stories with different approaches and diverse point of views. "Every station has its own market segmentation of audience. I believe RCTI producers have some specific treatment and language on composing their stories as their audience is those from A-B class. Their approach must be different than their colleagues in MNCTV whose positioning itself as $\mathrm{C}-\mathrm{D}$ class TV station. Language used in MNCTV should be simpler and easier to understand comparing to so-called high-class language in RCTI. But again, how far you can improvise as a producer if the original script and visual came from one single source? Producers from 4 TV stations work on the same story, using the same interviewees' answers to the same questions, using the same context, background and angle. How different your stories could be? Of course we can manage our final products not to look too similar, but the message remains," Informant A explains.

From economy standpoint, this practice shows the logic of capitalist behind media. Industrial synergies or integration becomes a strategy in optimising and centralising the production by ensuring profitability for content produced by journalists. News organisations, thus, prefer to re-use content, either articles or visual, in several of their titles. Economically, using one content for 4 outlets means double the revenue. Similar to that idea is "repurposing" concept (Killebrew, 2005:13). It stems from Parsimony Principle, in which organisations use the outputs of production in as many ways as possible. What should happen next, I would argue, is the multiplicity of content rather than diversity of content. From the media monitoring analyses, there were at least 5 topics found reported by the same team for no less than 3 outlets: Solo Bombing, Poso Terrorist Santoso, Kalijodo Relocation, Bukit Duri Relocation, and The Trial of Jessica Kumala Wongso, the accused cyanide coffee killer. Informant A adds, if the audience pay enough attention to MNC's regional news, they will find more multiplicity, as the regional bureaus have been integrated by 2008 , even long before the integration in Jakarta.

Apart from the economy standpoint, plurality and diversity of media content and media sources serve the public cause. Only by having diversity of media content and sources, one can find "the presence of a number of different and independent voices, and differing political opinions and representations of 
culture" (Doyle, 2002:12). This is why Ignatius Haryanto (2016, personal communication) underlines the importance of diversity of content and diversity of ownership in Indonesian media convergence and points out the issue of media ownership as the trigger. "For us in KNRP, it was crossownership which threatens diversity of content and diversity of ownership at the first place, especially in convergence era. Therefore, it is important for us to have clear and strict policy that regulates cross-ownership. Either within the Broadcasting Bill or Government Regulation, I think we must have it anyway, and it should reflect the spirit of diversity of content and ownership." There is nothing new in this proposal offered by Haryanto. In fact, the establishment of the Broadcasting Act of 2002 and the Indonesian Broadcasting Commission both aim at securing diversity in media ownership (decentralisation) and diversity in media content, which are also in line with the criteria of media in democratic society. Although in this case, Yuliandre Darwis (2016, personal communication), a Commissioner of Indonesian Broadcasting Commission gives more weight on diversity of content than diversity of ownership: "I think we concentrate more on monitoring the content. As for the ownership and broadcast licensing, I think we would prefer not to discuss about it further, at least not at the moment."

On broader aspect of convergence that is beyond horizontal convergence like MNC, Iman Nugroho (2016, personal communication) from the Alliance of Indonesian Independent Journalists warns the potential problem in journalistic products of convergence. "Each medium or platform needs specific journalistic treatment. Once media convergence takes place, surely the quality of journalistic output for each medium will not be the same. For instance if a reporter has to report for both print and online media, he has to sacrifice the quality of one of them. The reason is because online and print journalism have different characters. If you want to have quality print journalism product, you may not fulfil criteria of quality online journalism product, vice versa. Thus, I would say that in convergence era, the quality of journalism will be gradually decreased." Also, the implication of convergence is the so-called 'efficiency' by cutting staff. This creates a new term of 'multitasking' journalists.

\section{- Multitasking Journalists}

Multi-skilling appears to be more common in integrated newsrooms, where journalists produce content for multiple platforms (Wallace 2013; Van den Bulck and Tambuyzer 2013). As my case study is about the horizontal structural convergence of $4 \mathrm{TV}$ stations under MNC Media Gathering, the nuance may not multi-skills as if in multiplatform integrated newsroom. However, as we have already known now from Informant $\mathrm{A}$, an integrated newsroom does not need so many journalists anymore. What has already happened here might occur elsewhere that the number of journalists assessing events and addressing them is decreased. One team of a reporter and cameraperson is reporting for 4 TV outlets. They may have skills as broadcast journalists and have no obligation to produce for different platforms like online or print, yet their workload is 4 times increased.

When someone's workload is 4 times increased, the logical question following it would be: is his salary also 4 times increased or at least significantly higher than those who have a normal workload? It is unfortunately not. Informant A discusses how the recruitment in MNC Group now works. Once you get accepted, you will be offered a contract in which you will find a point that the employee understands that the company has 
rights to relocate any employees to other unit or department under the same group when necessary. No wonder, even if for example your status is an employee of MNCTV, might assign to GlobalTV. According to Iman Nugroho (2016, personal communication) from AJI Indonesia who often handles media workers issue, this practice has been a disadvantage for media workers. Hence he asks new journalists to be more critical when dealing with the company. "In this era of media convergence, everything should be clear from the start. Employees and Journalists must be active to advocate their industrial issues with the company." In the same tones as Nugroho, Ignatius Haryanto (2016, personal communication) suggests "fair compensation for media workers whom workload has been increased because of the convergence." Further he adds that it is the company's obligations to hold workshops or trainings for their media workers in order to make media people adaptive to work in the convergence era.

\section{- Owner's Agenda}

Last but not least, the implication of structural convergence is a political one. Half of the media owners listed in table 2 also serve as the leader of, or are closely related to, a political party. HaryTanoesoedibjo, the owner of Media Nusantara Citra (MNC) established a new party named Perindo (Partai Persatuan Indonesia, Indonesia in Unity Party) after his resignation from Hanura Party following his lost as vice-presidential candidate pairing with retired General Wiranto in the 2014 general elections. Before joining HanuraParty on 2013, Tanoesoedibjo was a member of NasdemParty (Partai Nasional Demokrat, National Democratic Party) founded and chaired by Surya Paloh, another media mogul and owner of the Media Indonesia Group
(MetroTV, Media Indonesia Daily). Aburizal Bakrie, the owner of TVone and ANTV (Visi Media Asia Group) is Chairman of GolkarParty.

Now let's talk about HaryTanoesoedibjo as the owner of PT. Global Mediacom, Tbk that holds Media Nusantara Citra as the case study for this research. Using the term from Informant $A$, the structural convergence has made the newsroom relatively easy to canalize the messages that are related to owner's agenda. Since the integration of news gathering division, MNC also established a dedicated division named Progsus (Program Kbusus or Special Program) desk. The main duty of this desk is to produce stories about Perindo or Hary Tanoe's political activities or stories that are inline with owner's preferences. At least one story produced by this division is mandatory to be allocated in each news program of all TV every day. Informant A (2016, personal communication) explains:

"The examples of stories produced by this team are ceremonials about Perindo and Hary Tanoe; and stories that favour his interests. There were times that we were not allowed to broadcast any story about (the Governor of Jakarta) Ahok (the nickname of Basuki Tjahja Purnama), either Ahok as a public figure or Ahok as the Governor, including his policies. The high-rank management staff once mentioned that any story about Ahok will make him more popular and $\mathrm{MNC}$ should not do that. It seems like he (Hary Tanoe) does not really like Ahok and his achievements. Thus, although lately there have been some stories related to Ahok on the screen, they are mostly discredited Ahok, like reclamation case or Sumber Waras corruption scandal. On the other hand, because Hary Tanoe has a special interest on land possession in Tangerang, we were not allowed to broadcast stories about the relocation of Dadap Village which is located in Tangerang, so Hary Tanoe can maintain good relation with the Regent." 
This case shows how strategic the media are, so it can be easily used as instrument to achieve owner's interests. Therefore, Haryanto emphasizes the importance of strong regulatory bodies in Indonesia. "In my opinion, media regulators take some great responsibilities to make such a transparent and impartial policy. It is also important for the regulator to feel authoritative and confident enough to guard the concept of diversity and also distinguish the direction of the future media policy in general, including technology and other complexity that follows." The real battle of independent media in which their owners are closely related to political party, thus, will be tested during the most crucial moment in democracy: the general election. Although this research does not go that far, these findings can be used for further research.

\section{Conclusion}

Since mass media have an impact on the way democracy functions, how media are governed must be considered crucial. Based on my findings using the case study of the structural convergence in MNC Group, we may see the obvious dangers of concentrated supply that potentially affects the democratic flow of information. It has therefore been seen to be necessary for regulatory controls to be developed within the converging communications market. In particular, regulators should be able to compose a policy that clearly ensures diversity of content, not multiplicity, within such services. With the intentions in securing diversity and national identity, regulatory bodies have rights to intervene in media business. As this research also shows clearly the strong relation between the issues of cross-ownership and convergence, KPI which also demand the inclusion of broadcasting sector should not hesitate to securing the diversity of ownership. Cross- ownership has strong tendency to eliminate a layer of voice. The company like MNC or others that own both the print and broadcast operations sets the voice for both organisations. In other words, regulators have to consider two main aspects of communication in democracy: (diversity of) voices and the marketplace of ideas.

Given the importance of broadcasting sector, it should be included in the Convergence Bill as the convergence is beyond the technological one. The future policy or regulation regarding convergence, then, must be able to foster a competitive market for all players and to ensure that general competition laws would be sufficient in themselves to stem any market dominance with regard to crossmedia ownership. I know this sounds idealistic as media policy is, in Pearce's words, 'a site of struggle' (2000: 353). However, I think the bottom line should be the principle of diversity of content and diversity of ownership. Thus, is the ongoing process of convergence creates and strengthens the conditions of diverse content and ownership? If not, how can the regulators make sure that this condition is achieved? Who is responsible to make this happen? Is it only the regulators? Which one? And how should we do if it is not happening? Those, however, are questions for another day.

\section{Acknowledgements}

I would like to thank LPDP for sponsoring me to the CCCMS 2016 and to my supervisor, Dr Edwin Jurriëns, who sent the link of the conference and for being very supportive all this time. Also for my colleagues in Asia Institute, the University of Melbourne who always being there when I spent most of my times at the study room: Sonja Petrovic, Guangyu Qiao, Yilu Yang, Pan Qiuping, and Dr Ken Setiawan. Special thanks to my Indonesian friends in Melbourne for the laughs we shared in 
the middle of those crazy days: Nelly, Prima, Randy, Mirza, Anggi, Wenny, Rangga, Deasy, Ikhsan. Thank you Informant A, Ignatius Haryanto, Iman Nugroho, Yuliandre Darwis for the interview sessions, and to Dandhy Dwi Laksono for always being a strong discussant of my ideas and thoughts. This time I make sure your name is correctly spelled. Last but not least, I would like to thank my husband, Laurensius Regi Aryoko for his love and supports, also my Mum and Dad for always have me in their prayers.

\section{Notes:}

1. Since its independence in 1945 until 1998, Indonesians have experienced 3 different political regimes. Sukarno applied 'Parliamentary Democracy' between 1950 and 1957 before he implemented 'Guided Democracy' from 1959 to 1965, followed by the 'New Order' regime under Suharto from 1967 to 1998.

2. Reformasior 'reform' is the post-New Order period, marked by the resignation of Suharto as a president after 32 years in 1998.
3. Here I refer only to national terrestrial television and exclude local television and pay television.

4. See Kemkominfo: Pengguna Internet Capai 82 Juta Orang. https://kominfo.go.id/index.php/content /detail/3980/Kemkominfo $\% 3 \mathrm{~A}+$ Penggun a+Internet + di+Indonesia + Capai+82+Juta /0/berita satker. Accessed: June 11th 2016

5. Lim (2011) found what she called 'The League of Thirteen' to describe the key players of Indonesian media ownership. However, she included also state-owned broadcasters on her list. It means, apart from the state-owned broadcasters, there were only 12 private media owners on her report. Nugroho et al. (2012) concluded the similar number of media owners. What both Lim and Nugroho missed from their list was Bali Post Group which I have included in Table 2.

6. In 2001, News Corp bought 20th Century Fox and put together a fourth network where others had failed. For further data about this, see Compaine (2001).

7. National Coalition for Broadcasting Reform (Koalisi Nasional Reformasi Penyiaran/ KNRP) is a loose coalition consists of Indonesian communication scholars and some media activists who share the same concern on broadcasting issues in Indonesia.

\section{Reference}

Bagdikian, B. 2004.The New Media Monopoly. Beacon Press

Buckley, M. 2008.Two Principles of Broadcast Media Ownership for a Democratic Society.Journal of Business Ethics Vol.82 p.821-834.

Caldwell, J. 2001. Introduction: Cultural Studies and the Global Political Economies of Television and Digital. Emergences, Volume 11, Number 1.pp.5-11

Compaine, B. November $8^{\text {th }} 2001$. The Myths of Global Media [online] Available at: http://www.opendemocracy.net/media -globalmediaownership/article 87.jsp [accessed: June 3rd 2016]
Compaine, B. November 22 $2^{\text {nd }}$ 2001. The Workable Real Vs The Absolutist Ideal [online] Available at: http://www.opendemocracy.net/media -globalmediaownership/article_239.jsp [accessed: June 3rd 2016]

Compaine, B. May $8^{\text {th }}$ 2002. A World Without Absolutes [online] Available at: http://www.opendemocracy.net/media -globalmediaownership/article 36.jsp [accessed: June 3rd 2016]

Day. L. 2006. Ethics in Media Communications. 5th ed. Boston: Wadsworth 
Di Era Online, Televisi Masih Menjadi Sumber BeritaUtama.http://www.techno.id/tec h-news/di-era-online-ini-tv-masihmenjadi-sumber-berita-utamamasyarakat-1511266.html. [accessed: June 11th 2016]

Doyle. G. 2002. Media Ownership: The Economics and Politics of Convergence and Concentration in the UK and European Media. London: Sage

Drucker, S \&Gumpert, G. 2010. Regulating Convergence. Peter Lang

Dryzek, J. \&Dunleavy, P. 2009. Theories of the Democratic State. Palgrave

Elections in Indonesia 2014.The Asia Foundation.http://www.aph.gov.au/ About_Parliament/Parliamentary De partments/Parliamentary_Library/pu $\mathrm{bs} / \mathrm{rp} / \mathrm{rp} 1314 / \mathrm{QG} /$ IndonesiaElectio ns. [accessed: June 11th 2016]

Erdal, I.J. 2007. Researching Media Convergence and Crossmedia News Production: Mapping the Field. Nordicom Review 28 (2007) 2, pp. 51 61

Flew, T. \& Swift, A.G. 2013. Regulating journalists? The Finkelstein Review, the Convergence Review, and News Media Regulation in Australia. Journal of Applied Journalism \& Media Studies, 2(1), pp. 181-199.

Garnham, N. \&Inglis, F. (1990). Capitalism and communication. Global culture and the economics of information. London: Sage Publications

Grant, A.E \& Wilkinson, J. 2009. Understanding Media Convergence: The Stata of the Field. Oxford University Press

Gundelsweiler, F \&Filk, F. 2012. Future Media Platforms for Convergence Journalism

Gillmor, D. 2006. We the Media: Grassroots Journalism By the People, For the People. O’Reilly Media

Goyette-Côté et al. 2012. Converging Journalism: Producing and publishing for multi-platform conglomerates in Canada. Journalism Studies. Volume 13 issues 5-6
Haryanto, I. 2011. Media ownership and its implication for journalists and journalism in Indonesia in Sen and Hill, 2011.Politics and the Media in Twenty-first Century Indonesia.Routledge: London and New York

Horwitz, R.B. 2005. On Media Concentration and the Diversity Question. The Information Society 21, pp.181-204

Indonesian elections 2014: JokowivsPrabowo. ABC News.

http://www.abc.net.au/news/201404-03/an-indonesia-votes2014/5364478. [accessed: June 11 th 2016]

Indonesia's 2014 national elections: a quick guide. Parliament of Australia. http://www.aph.gov.au/About Parlia ment/Parliamentary Departments/Pa rliamentary_Library/pubs/rp/rp1314 QQG/IndonesiaElections. [accessed: June 11th 2016]

Jenkins, H. 2006. Convergence Culture: Where Old and New Media Collide. New York University Press

Kemkominfo: Pengguna Internet Capai 82 Juta Orang. https://kominfo.go.id/index.php/con tent/detail $/ 3980 /$ Kemkominfo $\% 3 \mathrm{~A}+$ Pengguna+Internet + di + Indonesia $+\mathrm{C}$ apai+82+Juta/0/berita_satker. [accessed: June 11th 2016]

Killebrew, K.C. 2005. Managing Media Convergence. Blackwell Publishing

Levy, D.A. 2007. Regulating digital broadcasting in Europe: The limits of policy convergence. West European Politics, 20:4, 24-42.Routledge

Lim, M. 2011. @crossroads: Democratization of Media in Indonesia. Participatory Media Lab, Arizona State University and Ford Foundation

Lund, A.B. 2007. Media Markets in Scandinivia.Political Economy Aspects of Convergence and Divergence.Nordicom Review, Jubilee Issue 2007, pp. 121-134 
Masduki. 2014. Media Conglomeration and Political Intervention in 2014 General Election in Indonesia. GSTF Journal on Media \& Communications (JMC) Vol.2(1): 8-13

McChesney, R. October 24th 2001. Policing the Thinkable [online] Available at: http://www.opendemocracy.net/med ia-

globalmediaownership/article 56.jsp

[accessed: June 3rd 2016]

McChesney, R. November 14th 2001. Media Corporations Vs Democracy [online] Available at: http://www.opendemocracy.net/med $\underline{\mathrm{ia}-}$

globalmediaownership/article 60.jsp [accessed: June 3rd 2016]

McChesney, R. May 8th 2002. It's a Wrap: Why Media Matters to Democracy [online] Available at: http://www.opendemocracy.net/media -globalmediaownership/article 61.jsp [accessed: June 3rd 2016]

Meikle, G. \& Young, S. 2012. Media Convergence: Networked Digital Media in Everyday Life. Palgrave

Mugan, A and Gunther, R. (eds), 2000, Democracy and the Media : A Comparative Perspective, Cambridge University Press

Mulligan, C. 2012.The Communications of Industries in the Era of Convergence.Routledge

Nielsen: Konsumsi Media Lebih Tinggi di Luar Jawa.

http://www.nielsen.com/id/en/pressroom/2014/nielsen-konsumsi-medialebih-tinggi-di-luar-jawa.html. [accessed: June 11 th 2016]
Nugroho, Yanuar. et al. 2012. Mapping Media Policy in Indonesia. Research collaboration of Centre for Innovation Policy and Governance and HIVOS Regional Office Southeast Asia, funded by Ford Foundation. Jakarta: CIPG and HIVOS

Pearce, M. 2000. Structured action in Australian Broadcasting Policy: Pay TV. Media, Culture, and Society, vol.22, no.3, pp.347-354

Rianto et al, 2014. Kepemilikan dan intervensi siaran: Perampasan hak publik, dominasi, dan bahaya media di tangan segelintir orang. PR2Media. TIFA Foundation

Schultz, J. 1998. Reviving the Fourth Estate: Democracy, Accountability, and the Media. Cambridge University Press

Siapera, E. 2012.Understanding new media. SAGE. London

Sudibyo and Patria. 2013. The Television Industry in Post-authoritarian Indonesia. Journal of Contemporary Asia Vol.43 (2).Routledge: London and New York

Tapsell, R. 2011. 'Platform convergence in Indonesia: challenges and opportunities for media freedom', Convergence: The International Journal of Research into New Media Technologies, May 2011, vol. 21, no. 2, p. 182-197

Wheeler, M. 2001. Regulating Communication in the UK: A New Future. Sage

Winseck, D. 2008. The State of Media Ownership and Media Markets: Competition or Concentration and Why Should We Care? Sociology Compass 2/1 p.34-47 